\title{
Investigation of Angiogenesis and Wound Healing Potential Mechanisms of Zinc Oxide Nanorods
}

\author{
Amr Hassan ${ }^{1 *}$, Dalia Elebeedy ${ }^{2}$, Emadeldin R. Matar ${ }^{3}$, Aly Fahmy Mohamed Elsayed ${ }^{4}$ and \\ Ahmed I. Abd El Maksoud ${ }^{5,2}$ \\ ${ }^{1}$ Department of Bioinformatics, Genetic Engineering and Biotechnology Research Institute (GEBRI) University of Sadat City, \\ Sadat, Egypt, ${ }^{2}$ College of Biotechnology, Misr University for Science and Technology, Giza, Egypt, ${ }^{3}$ Department of Pathology, \\ Faculty of Medicine, Al-Azhar University, Cairo, Egypt, ${ }^{4}$ Holding Company for Vaccine and Sera Production (VACSERA), Giza, \\ Egypt, ${ }^{5}$ Department of Industrial Biotechnology, Genetic Engineering and Biotechnology Research Institute (GEBRI) University of \\ Sadat City, Sadat, Egypt
}

The angiogenesis process is an essential issue in tissue engineering. Zinc oxide nanorods are biocompatible metals capable of generating reactive oxygen species (ROS) that respond to induced angiogenesis through various mechanisms; however, released Zn (II) ions suppress the angiogenesis process. In this study, we fabricated green $\mathrm{ZnO}$ nanorods using albumin eggshell as a bio-template and investigate its angiogenic potential through chorioallantoic membrane assay and excision wound healing assay. This study demonstrated that angiogenesis and wound healing processes depend on pro-angiogenic factors as VEGF expression due to $\mathrm{ZnO}$ nanorods' exiting. Angiogenesis induced via zinc oxide nanorods may develop sophisticated materials to apply in the wound healing field.

Keywords: zinc oxide nanorods, angiogenesis, wound healing, VEGF, ROS

\section{INTRODUCTION}

Neovascularization is considered as an essential issue in regenerative medicine and tissue engineering (Ennett and Mooney, 2002). This issue has occurred via the microvascular process (Rouwkema et al., 2008). The angiogenesis process is the formation of novel capillary network to provide nutrients to cells (Folkman, 1984). Angiogenesis depends on factors like VEGF (Petrova et al., 1999), FGF (Ma, 2000), and angiopoietin activators of integrins (Suri et al., 1996). Although VEGF is an excellent, effective regulator to induce the angiogenesis process, there are enormous challenges to applying tissue engineering. The half-live of scaffolds is only a few minutes (Eliceiri and Cheresh, 1999). So, the presence of the material induces cells to produce VEGF, and FGF as a growth factor may help overcome these challenges. Previous studies reported that ROS functionalized in wound healing and cell proliferation throughout the activation of growth factors (Sen et al., 2002; Roy et al., 2006; Huo et al., 2009).

Abbreviations: VEGF, vascular endothelial growth factor.; ROS, reactive oxygen species; FT-IR, Fourier transformed infrared; XRD, X-ray diffraction; HRTEM, high-resolution transmission electron microscopy; HDF4, human dermal fibroblast cells HDF4; CAM, chicken chorioallantoic membrane; ZnO-NRs, zinc oxide nanorods; ICP-AES, inductively coupled plasmaatomic emission spectroscopy; DMEM, Dulbecco's modified Eagle medium 
Interestingly, ROS plays a prominent role in the angiogenesis process by activating key steps of cell proliferation, migration, and tube formation (Lelkes et al., 1998; Rhee, 2006; Xia et al., 2007; Augustine et al., 2014). $\mathrm{H}_{2} \mathrm{O}_{2}$ is considered as one of the ROS components, including in stages of angiogenesis. It contributes to the wound healing process by inducing VEGF expression in mice (Sen et al., 2002) and FGF in rat astrocyte cells (Pechan et al., 1992). Today, nanomedicine becomes one of the most important fields of nanotechnology and material science (Augustine et al., 2014). Over the past decade, there were many metal nanoparticle applications in biomedical applications such as diagnostic and therapeutic fields (quantum dots and semiconductors), anticancer therapy, antimicrobial therapy, and antiviral therapy. Zinc oxide $(\mathrm{ZnO})$ is an inorganic material classified as an FDAapproved material based upon its stability, safety, and intrinsic potential to neutralize UV radiations (Zhang et al., 2013). It has wide applications. $\mathrm{ZnO}$ nanoparticle is a promising material in biomedical applications such as antimicrobial, antigen, gene, drug delivery (Rasmussen et al., 2010), biosensor, and tissue engineering applications. Furthermore, Ayan et al. reported that $\mathrm{ZnO}$ nanoflowers could be inducing angiogenesis through proliferation and migration of endothelial cells (Barui et al., 2012; Augustine et al., 2014). Also, they mention that ROS stimulates angiogenesis by europium hydroxide [EuIII $(\mathrm{OH})_{3}$ ] nanorods (Patra et al., 2011).

\section{MATERIALS AND METHODS}

\section{Chemicals}

Zinc acetate hydrate was purchased from Sigma-Aldrich, United States, and albumin eggshells from Loba Chemical Co., Mumbai, India.

\section{Animals and Experimental Design}

We applied all the European Communities Council Directive (Directive 2010/63/EU of 22 September, 2010). According to the Institutional Animal Care and Use Committee at Cairo University, Egypt (IACUC, CU-II-F-10-19), we carried out the experimental procedure after the Animal Protocols Evaluation Committee's affirmative opinion. Sixty male albino Wister rats weighing approximately 170-200 g were brought from the Department of Veterinary Hygiene, Faculty of Veterinary Medicine, Sadat University, Egypt. According to the protocol, standard conditions for feeding, and living rats' before occurred experiments for ensuring animals in a healthy status

\section{Synthesis of ZnO Nanorods}

Several routes synthesized $\mathrm{ZnO}$ nanorods, but one of the best methods is the sol-gel method with some modifications (Nouroozi and Farzaneh, 2011). In a typical synthesis, 1.1 gram of zinc acetate dihydrate $\left[\mathrm{Zn}(\mathrm{CH} 3 \mathrm{COO})_{2} \cdot 2 \mathrm{H}_{2} \mathrm{O}\right]$ was added in $10 \mathrm{ml}$ of ultrapure water (Milli-Q water, United States) (18 M $\Omega$ ) containing 2 gm of albumin added gradually with $30 \mathrm{~min}$ stirring. The oven performed the calcination process at $300^{\circ} \mathrm{C}$ for $6 \mathrm{~h}$, and then, the precipitates were annealed slowly and characterized (Supplementary Figure S1).

\section{Zinc Oxide Nanorod Characterization}

A Fourier Transformed- Infrared spectrum (FT-IR) of the sample was recorded using the Nicolet 6700 apparatus (Thermo Scientific Inc., USA). The crystalline nature and grain size were studied by $\mathrm{XRD}$ patterns at $25-28^{\circ} \mathrm{C}$ with a D8 Advance X-ray diffractometer (Bruker, Germany). Shape and size of $\mathrm{ZnO}$ nanorods were determined using HRTEM, JSM-2100F, and JEOL Inc. (Tokyo, Japan) with a voltage of $15 \mathrm{Kv}$ and $200 \mathrm{KeV}$.

\section{Measurement of Released Zn (II) From Zinc Oxide Nanorods}

The protocol of measurement of released $\mathrm{Zn}$ (II) from zinc oxide nanorods was determined as previously described (Tada-Oikawa et al., 2015). The suspension solutions were diluted to $15 \mathrm{ml}$ of DMEM (GIBCO, United States) at $100 \mu \mathrm{g} / \mathrm{ml}$ concentration of $\mathrm{ZnO}$ nanorods. All samples were incubated at $37^{\circ} \mathrm{C}$ in a $5 \% \mathrm{CO}_{2}$ incubator for $1,3,6,12,18$, and $24 \mathrm{~h}$, and then cold-centrifuged at $10,000 \times \mathrm{g}$ for half an hour. Followed by which, the supernatant was aspirated and transferred into a test tube containing $0.5 \mathrm{ml}$ of concentrated nitric acid $\left(\mathrm{HNO}_{3} ;\right.$ Merck Inc, Germany). The resultant solution was completed up to $50 \mathrm{ml}$ with ultrapure water. So, the liberated $\mathrm{Zn}$ (II) was measured by ICP-AES-7500 (Perkin-Elmer, United States).

\section{Angiogenesis Mechanism by Quantitative RT-PCR} Human dermal fibroblast cells $\left(\mathrm{HDF}_{4}\right)$ (ATCC PCS201012, United States) were harvested in six-well plates, and then exposed to 10 and $20 \mu \mathrm{g} / \mathrm{ml}$ of suspended $\mathrm{ZnO}$ nanorods and $\mathrm{Zn}$ (II) ion (released from $100 \mathrm{mg} / \mathrm{ml}$ ) for $24 \mathrm{~h}$. Total RNA was isolated from cells posttreatment by using the RNeasy Mini Kit (Qiagen, Valencia CA, United States). The technical protocol for RNA extraction was according to the manufacturer's instructions (Pfaffl, 2001). The RNA concentration was measured through a Beckman dual spectrophotometer (United States). To quantify VEGF gene expression, the cDNA reverse transcriptase kit (Applied Biosystems, United States) was used to transfer the total RNA to cDNA. Then quantitative RT-PCR was carried out using the Syber Green I PCR Master Kit (Fermentas) (Applied Biosystems, USA); $2 \mu$ of template cDNA was then added to the final volume of $20 \mu \mathrm{l}$ of the reaction mixture. The procedures were carried out as the following enzyme activation for $10 \mathrm{~min}$ at $95^{\circ} \mathrm{C}$, followed by forty cycles to denature for $15 \mathrm{~s}$ at $95^{\circ} \mathrm{C}$, then annealing step for $20 \mathrm{~s}$ at $55^{\circ} \mathrm{C}$ and elongation step at $72^{\circ} \mathrm{C}$ for $20 \mathrm{~s}$. We used specific sets of primers for the target gene VEGF: TGCAGATTATGCGGATCAAACC- $3^{\prime}$ (forward) and 5' - GCA TTCACATTTGTTGTGCTGTAG-3' (reverse), and VEGF gene was normalized with $\beta$-actin gene which was used as an internal control. RT-PCR experiments were repeated three independent times.

\section{Reactive Oxygen Species Assay}

Human Dermal Fibroblast Cells $\left(\mathrm{HDF}_{4}\right.$ ) (ATCC PCS201012, USA) were treated with $\mathrm{ZnO}$ nanorods at $10 \mu \mathrm{g} / \mathrm{ml}, 20 \mu \mathrm{g} / \mathrm{ml}$, 
and $50 \mu \mathrm{g} / \mathrm{ml}$ concentrations, and $\mathrm{Zn}$ (II) ions were released at $100 \mu \mathrm{g} / \mathrm{ml}$ concentration for $24 \mathrm{~h}$. After treatment, the cells were washed and harvested in cold PBS $(+4 \mathrm{C})$. Then lysis of the cell pellets was performed by using a cell lysis buffer. Then cell pellets were centrifuged at a speed of $15,000 \mathrm{~g}$ for $10 \mathrm{~min}$ at $+4 \mathrm{C}$; the supernatant was maintained on ice until assayed for ROS assay. ROS was determined by using a ROS assay kit from Life Span Bioscience Inc. (Seattle WA, United States) following the manufacturer's instructions. Then $100 \mu \mathrm{l}$ of the sample, standard, and blank was added to each well, followed by an incubation period of $90 \mathrm{~min}$ at a temperature of $37^{\circ} \mathrm{C}$. All models were then aspirated, $100 \mu \mathrm{l}$ of biotinylated detection antibody was added to the plate, and then the latter was incubated for $1 \mathrm{~h}$ at $37^{\circ} \mathrm{C}$. After centrifugation $(3,000 \mathrm{~g})$, aspirate supernatants were washed in the plates three times by adding $100 \mu$ of HRP conjugate incubated at $37^{\circ} \mathrm{C}$ for half an hour. Supernatants were removed, and then, plates were washed several times. Before adding $90 \mu \mathrm{l}$ of TMB substrate solution and incubating at $37^{\circ} \mathrm{C}$ for $15 \mathrm{~min}$. Then, a stopping reaction occurred by adding $50 \mu \mathrm{l}$ of stop solution, followed which, the measurement of the absorbance at a wavelength of $450 \mathrm{~nm}$ was carried out via an ELISA plate reader, ELX-800 (Biotek, United States).

\section{Antioxidant Stress Biomarker}

Ellman's protocol was applied for evaluating a level of reduced glutathione (GSH) (Ellman, 1959). Measurement of glutathione was at $412 \mathrm{~nm}$, and the unit of GSH protein is $\mathrm{nmol} / \mathrm{mg}$.

\section{Chicken Chorioallantoic Membrane Assay}

For fertilizing, chicken eggs were supplied from the poultry station (Giza, Egypt). Under the aseptic condition, eggs were cracked gently, and their yolks were put in sterile plastic dishes. We were soaking filter paper discs with $\mathrm{ZnO}$ nanorod suspension solution with different concentrations (10, 20, and $50 \mu \mathrm{g} / \mathrm{ml}$ ), $\mathrm{Zn}$ (II) ions (released at $100 \mu \mathrm{g} / \mathrm{ml}$ concentration and incubated at a temperature of $37^{\circ} \mathrm{C}$ for $24 \mathrm{~h}$ ), and $10 \mathrm{ng}$ of VEGF that is known as a promoter of angiogenesis. It had worked as a positive control, while dimethyl sulphoxide (DMSO) worked as a negative control. We then placed all material (test, materials, and control (positive and negative)) on the egg yolks, and then incubated for $24 \mathrm{~h}$. After $24 \mathrm{~h}$ of the explosion, we took images using an Olympus camera of $10 \mathrm{MP}$ connected with a stereomicroscope. We used a manual method to count the new blood capillaries in a clockwise direction. The blood vessel branch was counted manually in a clockwise direction. Results were presented as the mean with standard deviation.

\section{Histopathological Examination of Chicken Chorioallantoic Membrane Assay}

On the second day after injection, the egg yolks were collected from each group ( $\mathrm{ZnO}$ nanorods $(10,20$, and $50 \mu \mathrm{g} / \mathrm{ml}$ ), $\mathrm{Zn}$ (II) ions (released at $100 \mu \mathrm{g} / \mathrm{ml}$ ), and $10 \mathrm{ng}$ of VEGF) in PBS of pH 7.4 solutions, followed by a fixation step with $10 \%$ neutral-buffered formalin. The preparation of specimens for histological examination was according to Bancroft et al. (Velnar et al., 2009). The interpretation of results by a ranking score indicated the degree of branching vessel and branching patterns. The specimen section photographs were taken and observed for angiogenesis (Ausprunk et al., 1975; Norrby, 2006). Repeat experiments were carried out with three independent experiments.

\section{Wound Healing Study (Excision Wound Model)}

Initially, the animals were anesthetized using ketamine $(100 \mathrm{mg} /$ $\mathrm{ml})$ and xylazine $(20 \mathrm{mg} / \mathrm{ml})$ in a $3: 1 \mathrm{v} / \mathrm{v}$ ratio, and subsequently, a piece of the skin $(14 \mathrm{~mm})$ was removed surgically from the dorsal region of each mouse. After skin excision, the wound was cleaned initially with diluted soap $50 \%$ in saline and rinsed with saline solution. Then wound groups (II and III) were treated with $\mathrm{ZnO}$ nanorods at concentration of $10 \mu \mathrm{g} / 200 \mu \mathrm{l}$ and $20 \mu \mathrm{g} / 200 \mu \mathrm{l}$. Phenytoin (Pitiakoudis et al., 2004) was applied as a standard positive control for group IV. The mice's maintenance was followed in individual cages with total care under a warming lamp until its recovery from anesthesia. The total wound area was scaled daily for 14 days (the experiment time). Alternatively, the clinical condition of mice (Thomas, 1990) (e.g., total wound area and the healing process's progress) was recorded daily for 14 days (the experiment time). Skin images for photo documentation were acquired using an Olympus camera (Olympus, Tokyo, Japan) at a fixed distance of $30 \mathrm{~cm}$ perpendicular to the subject. The photographs were digitized, and the wound area was measured using Adobe Photoshop C5. After 14 days, acceptable euthanasia methods (decapitation method) were applied to sacrifice the mice (Clifford, 1984). Followed by excised skin tissue, skin sections of specimens from all groups were performed using a paraffin microtome (Shandon Finesse, Thermo Fisher Scientific, Cheshire, United Kingdom) and stained with hematoxylin and eosin stain kit (Atom Scientific, Cheshire, United Kingdom). Parameters such as inflammation and skin structure were estimated. The Walker equation evaluated the wound healing percentages after measurement of the wound area.

$$
\text { Wound area }=\frac{\text { Wound area in the day } \mathrm{X}}{\text { Wound area at the beginning }} \times 100 \text {. }
$$

\section{STATISTICAL ANALYSIS}

Statistical analysis was carried out using the variance (ANOVA) single factor test analysis with significance at $p<0.05$.

\section{RESULTS}

\section{Zinc Oxide Nanorod Characterization FT-IR Spectroscopy}

FT-IR spectra of zinc oxide nanorods ( $\mathrm{ZnO}-\mathrm{NRs}$ ) are shown in Figure 1. The wave band at $3415-3503 \mathrm{~cm}^{-1}$ indicated $\mathrm{O}-\mathrm{H}$ stretching vibration that of Jong-hun et al. Borah et al. (2016) mentioned a band at $3503 \mathrm{~cm}^{-1}$ for $\mathrm{O}-\mathrm{H}$ stretching vibration in the $\mathrm{ZnO}$ nanomaterials. Furthermore, hydroxyl groups' presence is due to a sharp band's appearance with intensity at $1136 \mathrm{~cm}^{-1}$. 


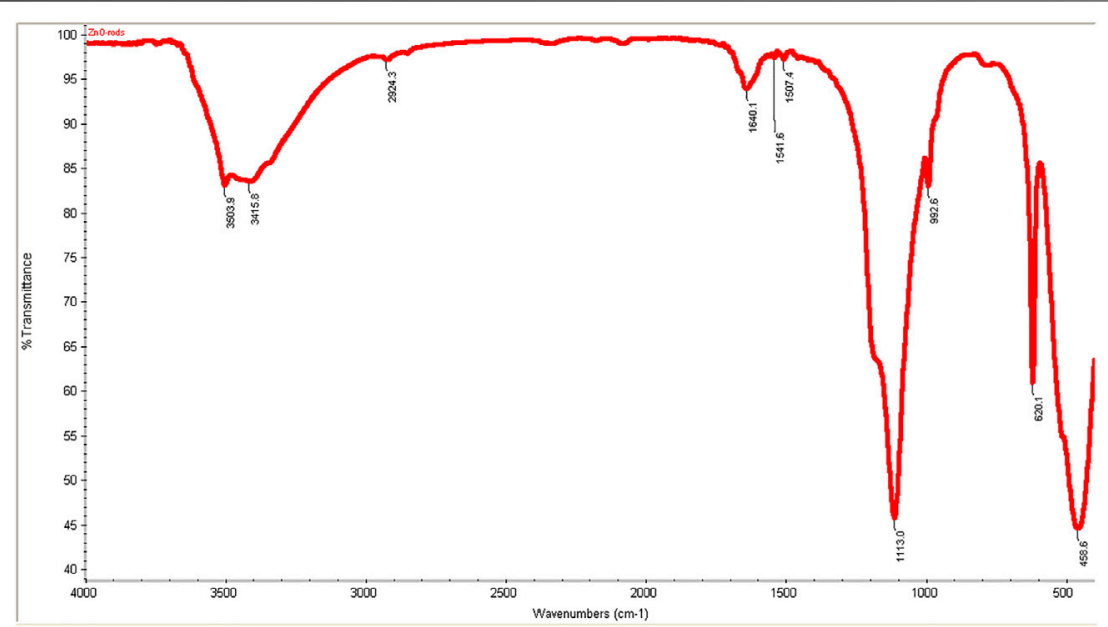

FIGURE 1 | FT-IR spectra ZnO nanorods (ZnO-NRs).

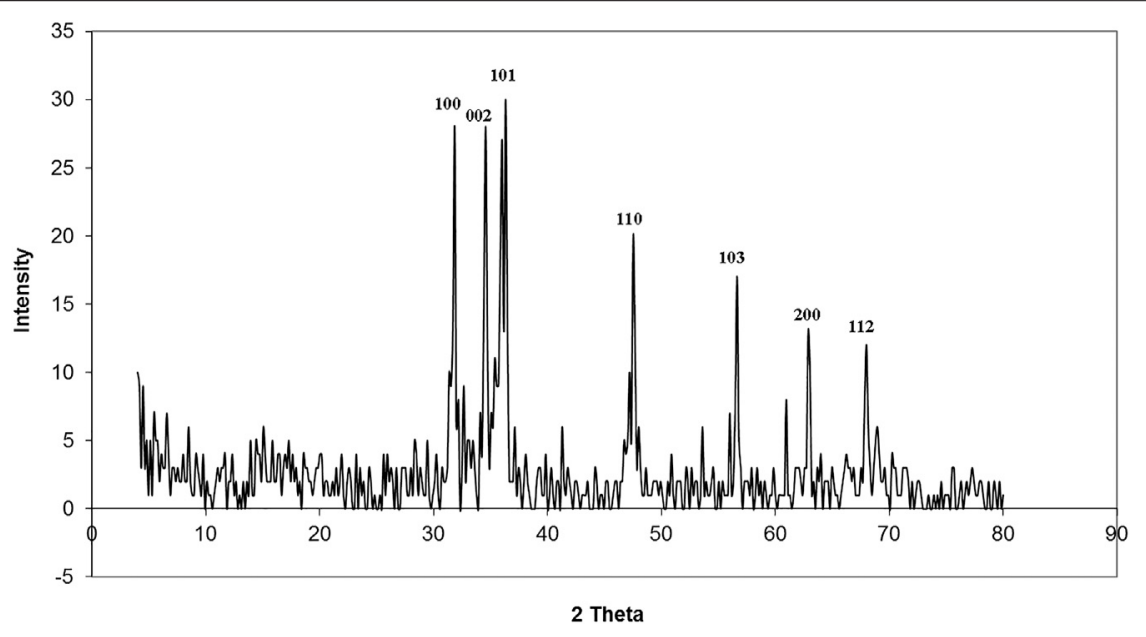

FIGURE 2 | XRD patterns of $\mathrm{ZnO}$ nanorods (ZnO-NRs).

This peak refers to $\mathrm{O}-\mathrm{H}$ in-plane bending vibration. A strong band at $458 \mathrm{~cm}^{-1}$ was indicated or referred to as the $\mathrm{Zn}-\mathrm{O}$ bond. The result supported that the appearance of hydroxo, oxo, or aqua species on the surface of zinc oxide nanorods was due to the existence of excess oxygen content in the nanomaterial (Silverstein and Bassler, 1962; Farmer, 1974).

\section{X-Ray Diffraction}

$\mathrm{XRD}$ patterns of $\mathrm{ZnO}$ nanorods are shown in Figure 2. The peaks at $2 \theta=31.746,34.395,36.226,47.526,56.549,62.832,67.893$, and 69.028 were assigned to (100), (002), (101), (110), (103), (200), (112), and (201) of $\mathrm{ZnO}$ nanorods. All peaks indicated a hexagon wurtzite structure (Zincite, JCPDS no, 89-0510). The results indicated the high quality of $\mathrm{ZnO}$ nanorods. The average crystal sizes of $\mathrm{ZnO}-\mathrm{NRs}$ obtained after calcination at $300^{\circ} \mathrm{C}$ for five hours have confirmed their rod shape with $285 \mathrm{~nm}$ length and $84 \mathrm{~nm}$ diameter. Scherer's equation (Patterson, 1939; Cullity and Stock, 2001) evaluated the average crystallite size (4) of $\mathrm{ZnO}-\mathrm{NRs}$.

$$
d=k N \beta \cos \theta
$$

where $k=0.9$ is the shape factor, $\beta$ is the measured FWHM, $\theta$ is the Bragg angle of the peak, and $\lambda$ is the XRD wavelength.

\section{Morphological Studies of ZnO-NRs}

The identification of morphology, size, and diffraction lattice of zinc oxide nanorods was carried out using transmission electron microscopy. TEM analysis of ZnO-NRs confirmed their rod shape with the dimensions of $285 \mathrm{~nm}$ length and $84 \mathrm{~nm}$ diameter and diffraction index as shown in Figures 3, 4; Supplementary Figure S2. The obtained results are in total agreement with the results of the XRD data presented in Figure 2. 


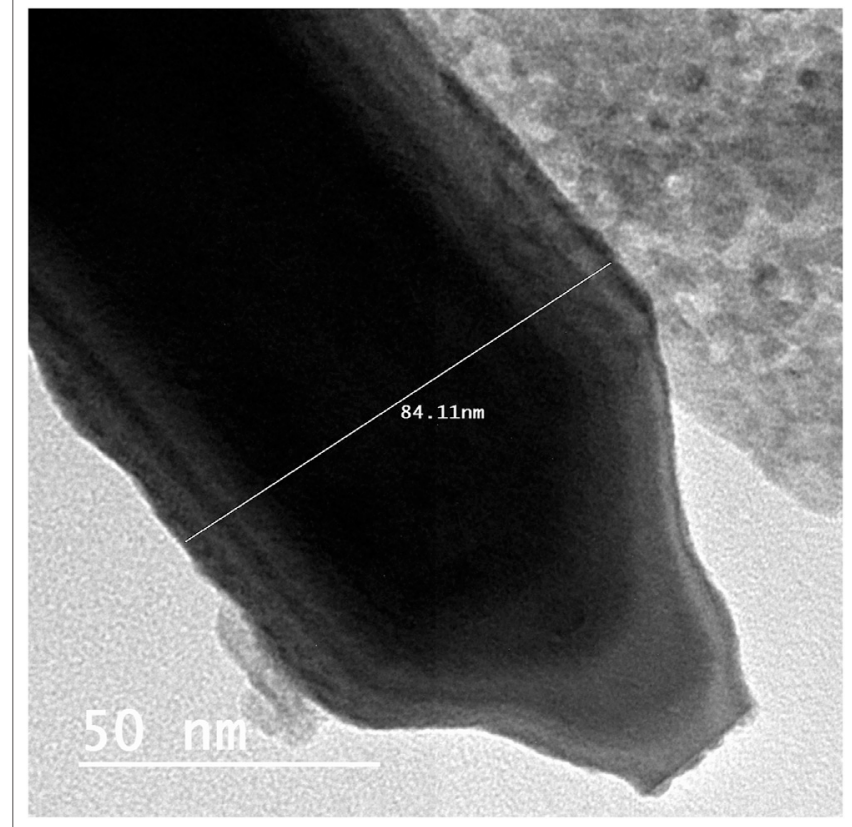

FIGURE 3 | Transmission electron microscopy of ZnO nanorods (ZnO-NRs).

\section{Measurement of Released Zn (II) From Zinc Oxide Nanorods}

ICP-AES was used to measure the quantity of $\mathrm{Zn}$ (II) ion liberated to the supernatant of the dispersed $100 \mu \mathrm{g}$ of $\mathrm{ZnO}$-NRs after $24 \mathrm{~h}$. As shown in Figure 5, the Zn (II) ion's total amount was altered with different time intervals. The data also indicated that the amounts of $\mathrm{Zn}$ (II) ion released from $\mathrm{ZnO}-\mathrm{NRs}$ were $23 \mathrm{ppm}$ after $24 \mathrm{~h}, 18 \mathrm{ppm}$ after $18 \mathrm{~h}, 15 \mathrm{ppm}$ after $12 \mathrm{~h}, 11.5 \mathrm{ppm}$ after $6 \mathrm{~h}$, $6.5 \mathrm{ppm}$ after $3 \mathrm{~h}$, and $1.5 \mathrm{ppm}$ at $1 \mathrm{~h}$.

\section{Quantitative RT-PCR}

Real-time PCR was used to investigate the gene expression of VEGF. As shown in Figure 6, the VEFG gene was significantly upregulated with $\mathrm{ZnO}-\mathrm{NR}$ concentrations $(10 \mu \mathrm{g}, 20 \mu \mathrm{g}$, and $50 \mu \mathrm{g})$, while the VEFG gene was significantly downregulated in the case of released $\mathrm{Zn}(\mathrm{II})$ ion $(p<0.05)$. The fold change of $10 \mu \mathrm{g}$ of $\mathrm{ZnO}-\mathrm{NRs}$ is double-fold superior to that of the non-treated control cells. Also, $20 \mu \mathrm{g}$ of $\mathrm{ZnO}-\mathrm{NRs}$ is fourfold superior to that of the non-treated control cells; also, $50 \mu \mathrm{g}$ of $\mathrm{ZnO}-\mathrm{NRs}$ is tenfold more remarkable than the control cells. VEFG expressions were increased relative to the increased $\mathrm{ZnO}-\mathrm{NRs}$. In contrast, the released $\mathrm{Zn}$ (II) ion was half of the value control cell, as shown in Figure 6.

\section{Reactive Oxygen Species Assay}

Figure 7 showed that ROS increased relatively to concentration of ZnO-NRs: $10 \mu \mathrm{g} / \mathrm{ml}$ (14\%), $20 \mu \mathrm{g} / \mathrm{ml}(29 \%)$, and $50 \mu \mathrm{g} / \mathrm{ml}(49 \%)$ compared with the untreated cell control value. Released $\mathrm{Zn}$ (II) ion showed no positive effect, indicating that only $\mathrm{ZnO}-\mathrm{NRs}$ induced reactive oxygen species, and $\mathrm{Zn}$ (II) ion released did not contribute to the angiogenesis process.

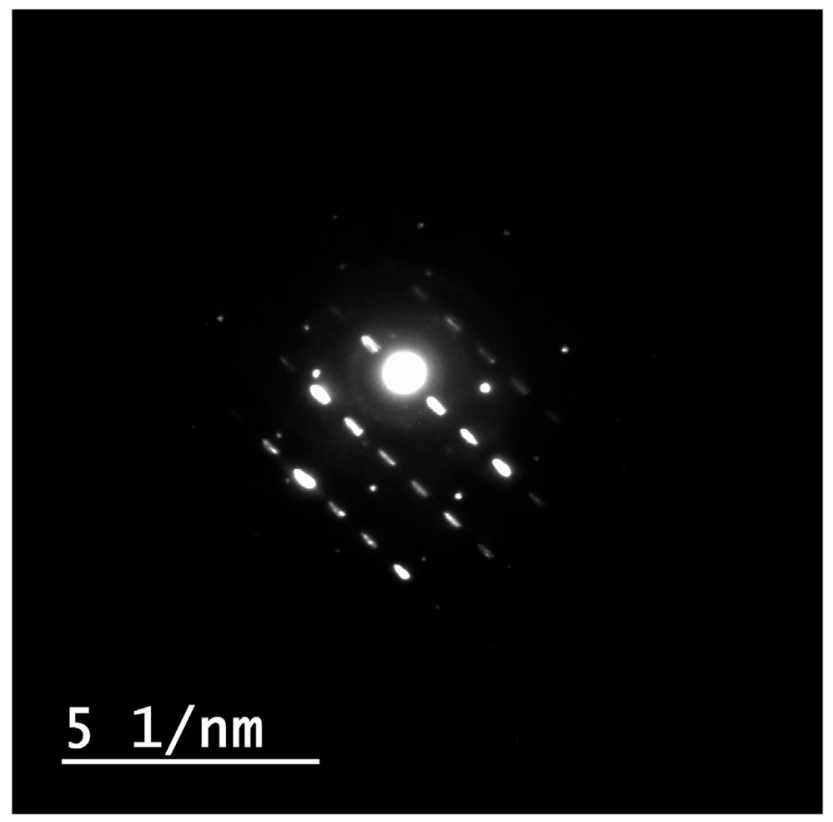

FIGURE 4 | Diffraction index of ZnO nanorods (ZnO-NRs).

\section{Antioxidant Stress Biomarker}

Glutathione peroxidase enzyme favors the removal of hydrogen peroxide by catalyzing its reaction with reduced glutathione (GSH) according to the following reaction (Marklund s., 1982):

$$
\mathrm{H} 2 \mathrm{O} 2+2 \mathrm{GSH} \rightarrow 2 \mathrm{H} 2 \mathrm{O} 2+\text { GSSG }
$$

Figure 8 showed that glutathione of $\mathrm{ZnO}-\mathrm{NR}$ concentrations of $10 \mu \mathrm{g} / \mathrm{ml}, 20 \mu \mathrm{g} / \mathrm{ml}$, and $50 \mu \mathrm{g} / \mathrm{ml}$ treated with $\mathrm{HDF} 4$ cells increased compared to the untreated cell control. It indicated that $\mathrm{ZnO}-\mathrm{NRs}$ behaved as an influential precursor of hydrogen peroxides. Due to GSH peroxidase with $\mathrm{ZnO}-\mathrm{NR}$-treated cells, glutathione decreased by $25 \%, 35 \%$, and $40 \%$ compared to the untreated cell control, while released $\mathrm{Zn}$ (II) ion had no positive effect, indicating that $\mathrm{ZnO}-\mathrm{NRs}$ contribute to producing $\mathrm{H}_{2} \mathrm{O}_{2}$ that promotes the angiogenesis process.

\section{Chicken Chorioallantoic Membrane Assay}

The chicken chorioallantoic membrane (CAM) assay considers a standard assay that measures the pro-angiogenic material potential. CAM assay has investigated the performance of $\mathrm{ZnO}-\mathrm{NRs}$ to induce the microvascular process. After $24 \mathrm{~h}$ of remediation, the images were taken by Olympus camera. Interestingly, there was an increase in length, size, and junction as shown in Figures 9,10A-D that revealed $\mathrm{ZnO}$ NRs with concentrations of $10 \mu \mathrm{g} / \mathrm{ml}$ and $20 \mu \mathrm{g} / \mathrm{ml}$, and positive control VEGF (10 ng) increased the formation of matured vascular sprouting significantly as compared with a negative control. The percentages of increase in the length were $2.5,3.5$, and 4.5 fold. Also, the percentage of increase in size was $2.25,3.25$, and 3.75 , and the injunction was $2,2.5$, and 4 fold for $\mathrm{ZnO}-\mathrm{NRs}(10 \mu \mathrm{g} / \mathrm{ml}$ and $20 \mu \mathrm{g} / \mathrm{ml})$ and VEGF (10 ng), 


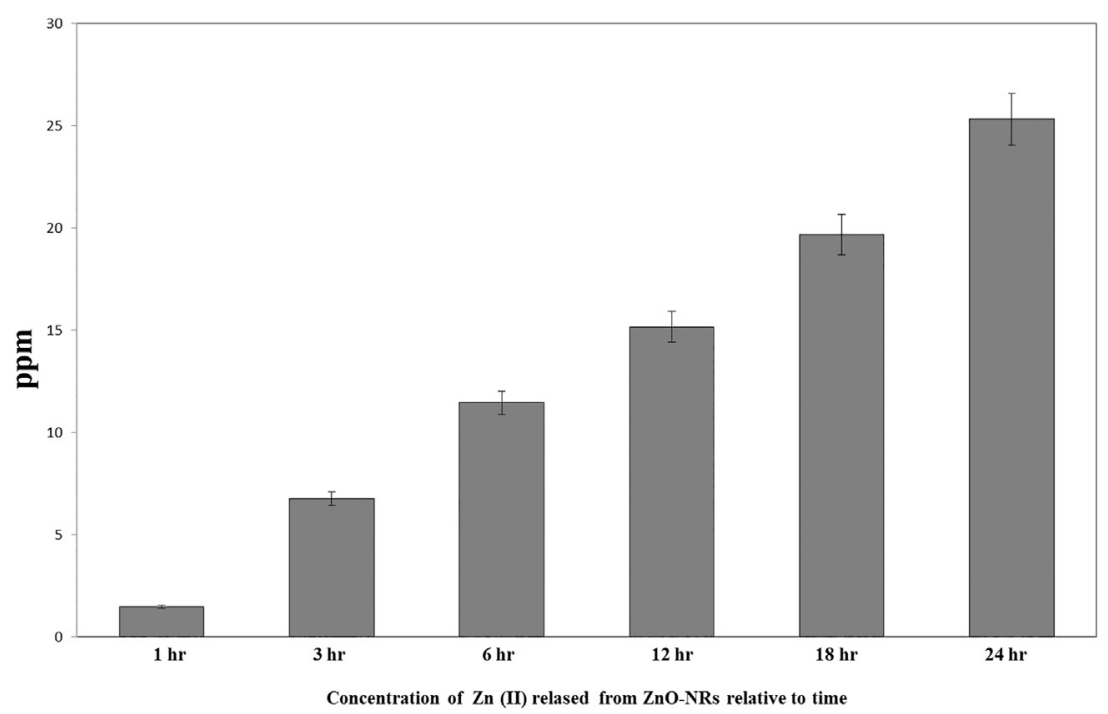

FIGURE 5 | Released zinc (II) ions from ZnO nanorods by ICP-AES.

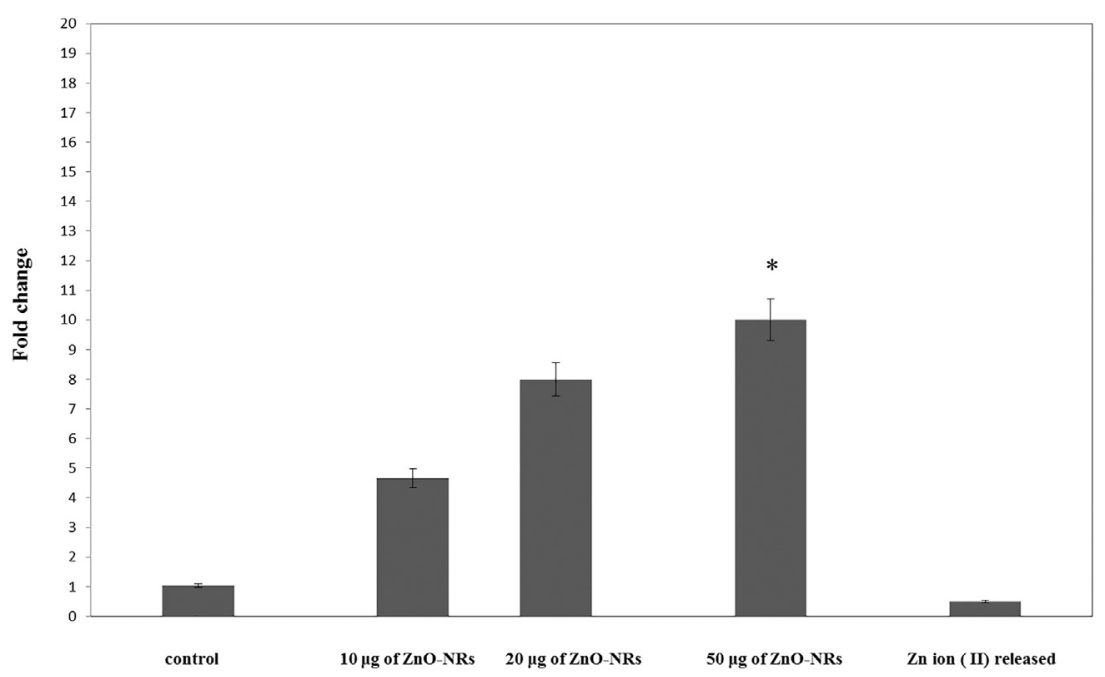

FIGURE 6 | Quantitative real-time PCR measures mRNA levels of the vascular endothelial growth factor gene (VEGF).

respectively, superior to that of the control. In contrast, Figures 9,10E,F demonstrated that $\mathrm{ZnO}-\mathrm{NRs} 50 \mu \mathrm{g}$ and liberated $\mathrm{Zn}$ (II) ions decreased vascular sprouting in length were 0.5 and 0.75 , in sizes were 0.4 and 0.5 , and injunctions were 0.6 and 0.5 . Figures 9,10 displayed the effective influence of $\mathrm{ZnO}-\mathrm{NR}$ concentrations with $10 \mu \mathrm{g} / \mathrm{ml}$ and $20 \mu \mathrm{g} / \mathrm{ml}$ on length and size, respectively, and junction as pro-angiogenic material potential.

\section{CAM Histopathological Examination}

The histopathological pattern of the chick embryo chorioallantoic membrane treated with ZnO-NRs, VEGF, and released $\mathrm{Zn}$ (II) ion investigates angiogenesis. Hematoxylin and eosin-stained CAM sections, as shown in Figure $11 \mathrm{C}$ revealed CAM exposed to $\mathrm{ZnO}-$
NR concentration of $20 \mu \mathrm{g} / \mathrm{ml}$ showed well-developed neovascularization with a score of +3 , which represented numerous branching patterns of blood vessels more than $\mathrm{ZnO}$ NR concentration of $10 \mu \mathrm{g} / \mathrm{ml}$ with a score of +2 in Figure 11B. Both of $\mathrm{ZnO}-\mathrm{NR}$ concentrations, $10 \mu \mathrm{g} / \mathrm{ml}$ and $20 \mu \mathrm{g} / \mathrm{ml}$, had had better vascularization than the negative control (score 0 ), as shown in Figure 11A. Similarly, Figure 11D represented the CAM exposed to $10 \mathrm{ng}$ of VEGF as a positive control with a score of +4 . However, Figure 11E showed fewer vascular vessels due to exposure to released $\mathrm{Zn}$ (II) ions with a score of +1 , and Figure $\mathbf{1 1 F}$ showed a minor vascular vessel due to exposure to $50 \mu \mathrm{g}$ with a score of zero. Table 1 interpreted the scores of the histological feature according to Ejaz et al. (2006) and Bao et al. (2012). The 


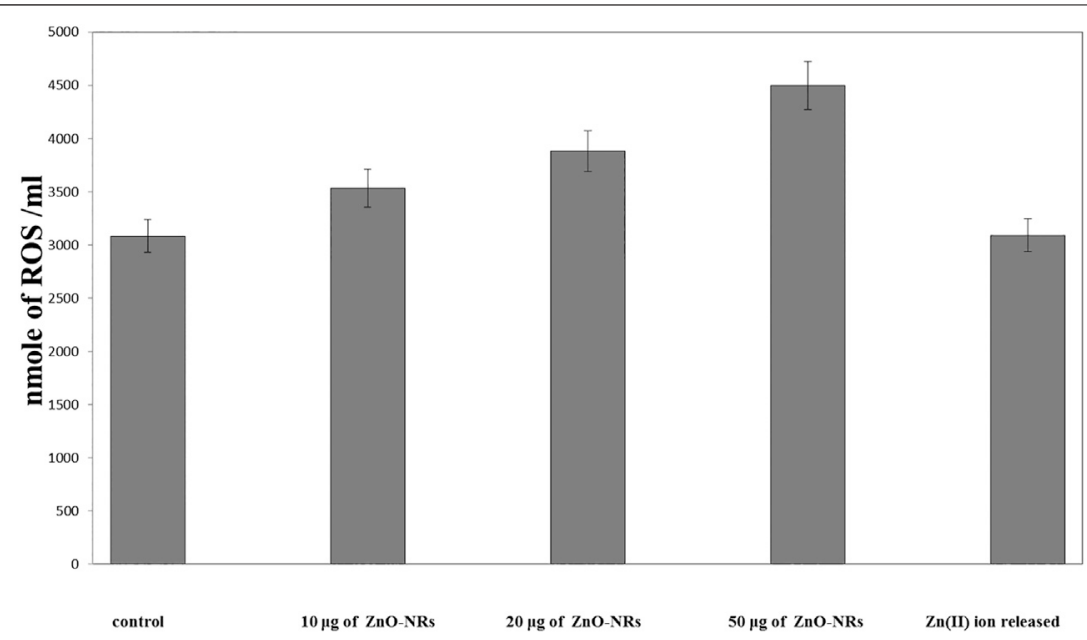

FIGURE 7 | Reactive oxygen species (ROS) of ZnO nanorods (ZnO-NRs) and released zinc (II) ions from ZnO nanorods (ZnO-NRs).

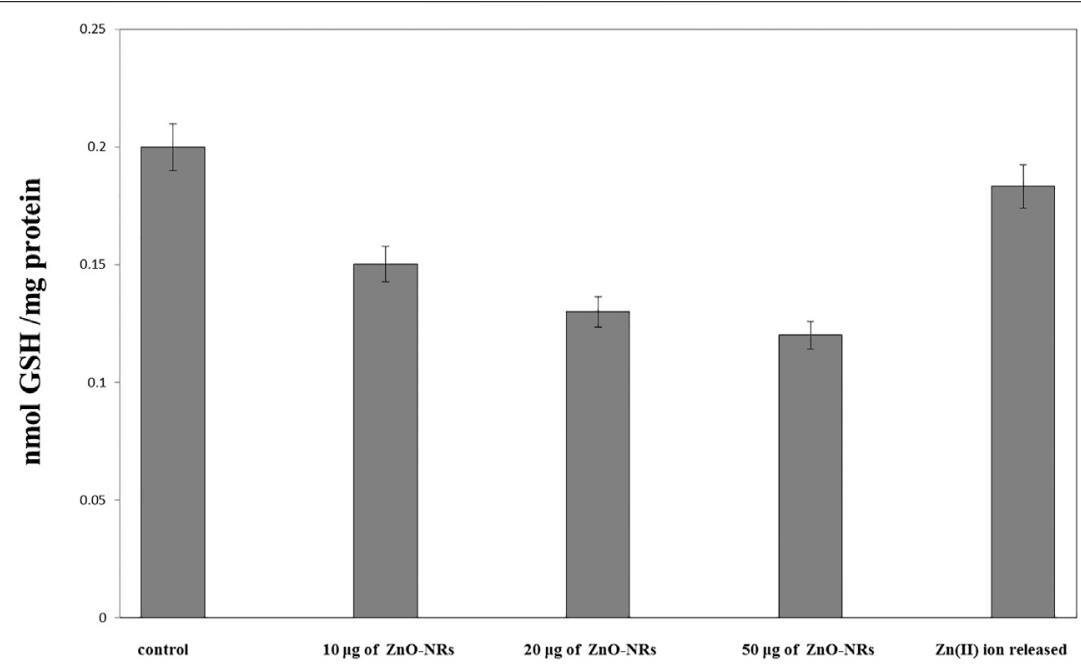

FIGURE 8 | Glutathione peroxidase enzyme of ZnO nanorods (ZnO-NRs) and released zinc (II) ions from ZnO nanorods (ZnO-NRs).

histological examination displayed those excess blood vessels with the highly branched network. These views support the angiogenesis activity induced by $\mathrm{ZnO}$ nanorods.

\section{In Vivo Implantation Study (Morphology of Wound Healing)}

Based on the results of the in vitro assay and CAM assay studies, $\mathrm{ZnO}-\mathrm{NRs}$ with concentrations of $10 \mu \mathrm{g} / \mathrm{ml}$ and $20 \mu \mathrm{g} / \mathrm{ml}$ and phenytoin (used as standard positive control) were selected for animal implantation studies to investigate in vivo angiogenesis. As shown in Figure 12, the initial skin wound appeared clearly with $14 \mathrm{~mm}$. After 5 days, the wound healing percentage increased slightly compared with the non-treated control group (I). The percentages of wound healing using $\mathrm{ZnO}-\mathrm{NRs}$ with concentrations of $10 \mu \mathrm{g} / \mathrm{ml}$ and $20 \mu \mathrm{g} / \mathrm{ml}$ were 20 and $28 \%$, respectively, compared with $12 \%$ of the negative control (non- treated). Similarly, the percentage of wound healing using phenytoin was $35 \%$. After ten days, the percentages of wound healing increased to $46 \%, 59 \%$, and $67 \%$ for $\mathrm{ZnO}-\mathrm{NRs}$ with concentrations of $10 \mu \mathrm{g} / \mathrm{ml}$ and $20 \mu \mathrm{g} / \mathrm{ml}$ and phenytoin compared with the percentage of wound healing in negative control, which was $35 \%$. After 14 days, the percentages of wound healing increased to $63 \%, 84 \%$, and $93 \%$ for $10 \mu \mathrm{g} / \mathrm{ml}$, $20 \mu \mathrm{g} / \mathrm{ml}$, and phenytoin, respectively, compared with the negative control with a percentage of 55\%. This result indicated that dressing with $\mathrm{ZnO}-\mathrm{NRs}$ accelerates the healing of open-excision type wounds in vivo. Figure 13 displayed the wound healing mechanism. After five days of treatment, Figures 13E-H demonstrated the thickening edematous and hotness of the epidermis at the injury edge. Interestingly, filling the wound gap with necrotic tissues and then filling the wound area with mature granulation tissues are shown in Figures 13E-H. Finally, 


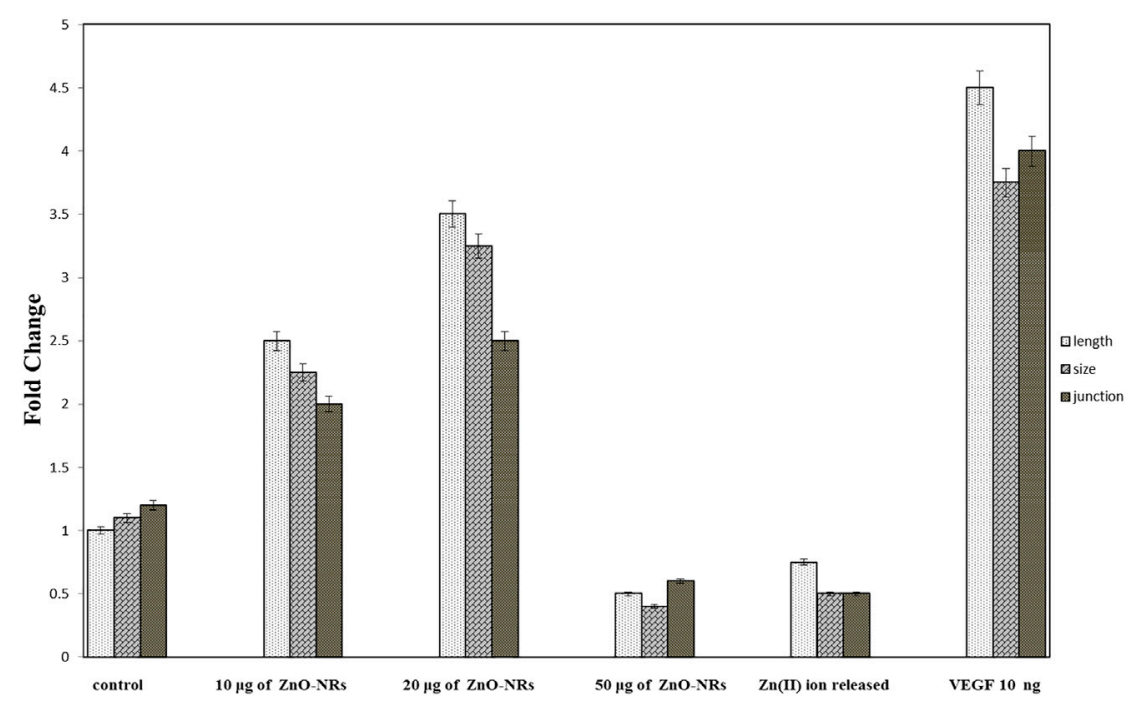

FIGURE 9 | Angiogenesis parameter quantitative of ZnO nanorods (ZnO-NRs) and released zinc (II) ions using chicken chorioallantoic membrane (CAM) assay.

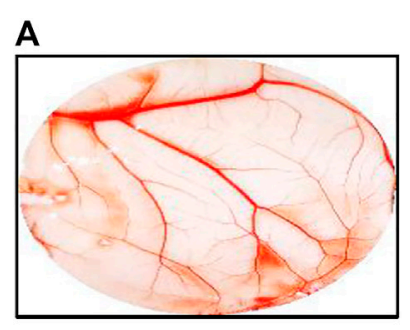

D

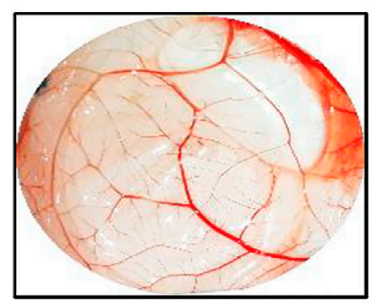

B

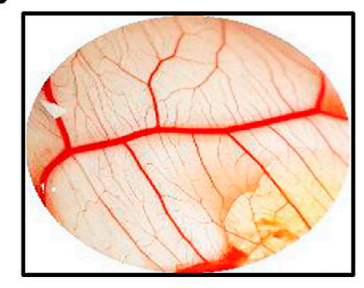

E

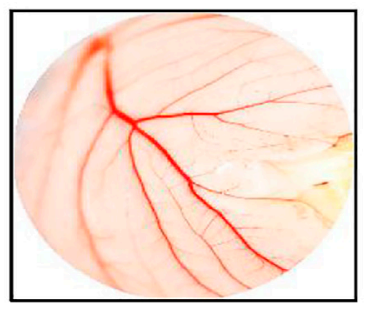

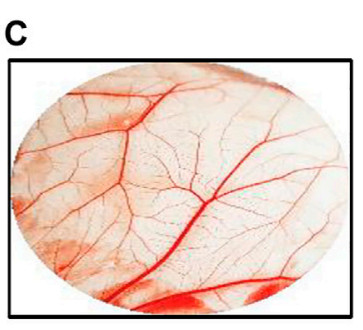

$\mathbf{F}$

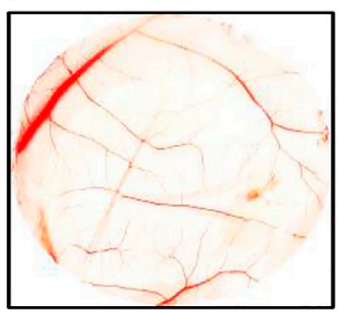

FIGURE 10| Chicken chorioallantoic membrane (CAM) assay. (A) Negative control (non-treated). (B) CAM treated with $10 \mu \mathrm{gg} / \mathrm{ml}$ of ZnO nanorods (ZnO-NRs). (C) CAM treated with $20 \mu \mathrm{g} / \mathrm{ml}$ of ZnO nanorods (ZnO-NRs). (D) CAM treated with $10 \mathrm{ng}$ of positive control VEGF. (E) CAM treated with $50 \mu \mathrm{gg} / \mathrm{ml}$ of ZnO nanorods (ZnONRs). (F) CAM treated with released Zn (II) ions.

Figures 13I-L displayed that wound gaps were shrinking due to the rate of epithelialization. As a result, $\mathrm{ZnO}-\mathrm{NR}$ concentrations were found to show their contributory role in the accelerating epithelialization rate and required lesser time to complete the epithelialization process than the negative control.

\section{Histological Explanation of Wound Healing}

After three days of treatment with ZnO-NRs with concentrations of $10 \mu \mathrm{g} / \mathrm{ml}$ and $20 \mu \mathrm{g} / \mathrm{ml}$ and phenytoin as standard drugs, Figures 14B-D showed that the dermis near the excision was rich with inflammatory cells, mainly polymorphonuclear cells with an insufficient number of fibrosis in the outer skin near the injury area. On the other side, a control skin tissue section (untreated skin tissue) shows cellular or rare endothelial cells with zero scores, as Figure 14A showed. As Figures 14B-D indicated, the healing process started and the neo-angiogenesis process begun with a score of +1 . After five days of treatment with ZnO-NRs with concentrations of $10 \mu \mathrm{g} / \mathrm{ml}$ and $20 \mu \mathrm{g} / \mathrm{ml}$ and phenytoin as standard drugs, Figures 14E-H showed the fibrin net rich in inflammatory cells, mainly neutrophils, macrophages, and lymphocyte skin tissue of all groups (control, standard, and test material). Moreover, the reform of a cuticle was inhibited ultimately-also, observation of moderate propagation emigration of fibroblasts and mild new collagen. Control 

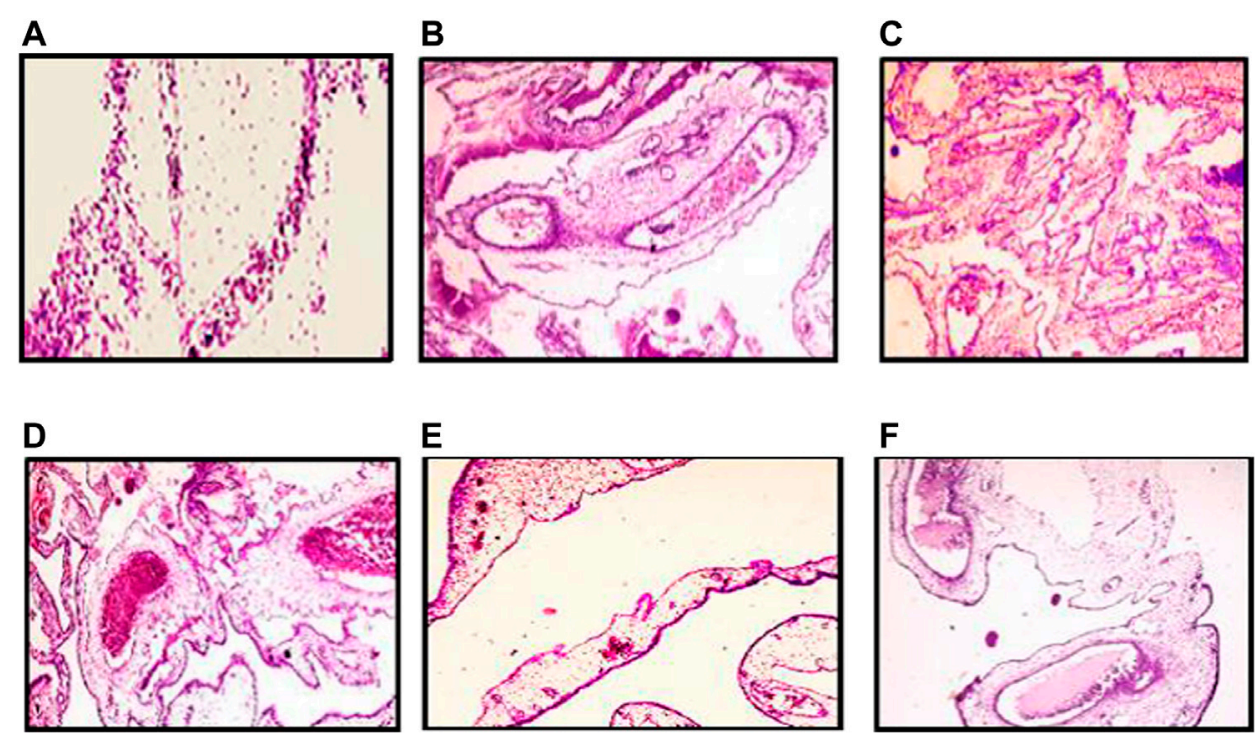

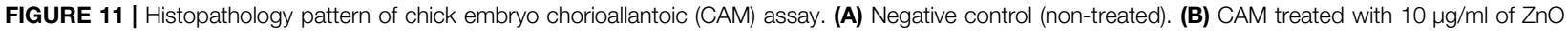
nanorods (ZnO-NRs). (C) CAM treated with $20 \mu \mathrm{g} / \mathrm{ml}$ of ZnO nanorods (ZnO-NRs). (D) CAM treated with $10 \mathrm{ng}$ of positive control VEGF. (E) CAM treated with $50 \mu \mathrm{gg} / \mathrm{ml}$ of $\mathrm{ZnO}$ nanorods (ZnO-NRs). (F) CAM treated with released $\mathrm{Zn}$ (II) ions.

TABLE 1 | Angiogenesis score concerning histological feature

\section{Score}

Histological feature

0
1
2
3
4

It referred to cellular or rare endothelial cells

It illustrated that dispersed small aggregate endothelial cells without lumens

It indicated those endothelial cells in all parts of the section with some tube formation

It elucidates that readily identified capillary tube forming that includes RBCs and small amounts of collagen

It represented that those vast vessels have more than four red cells containing layers of collagen in vessel walls

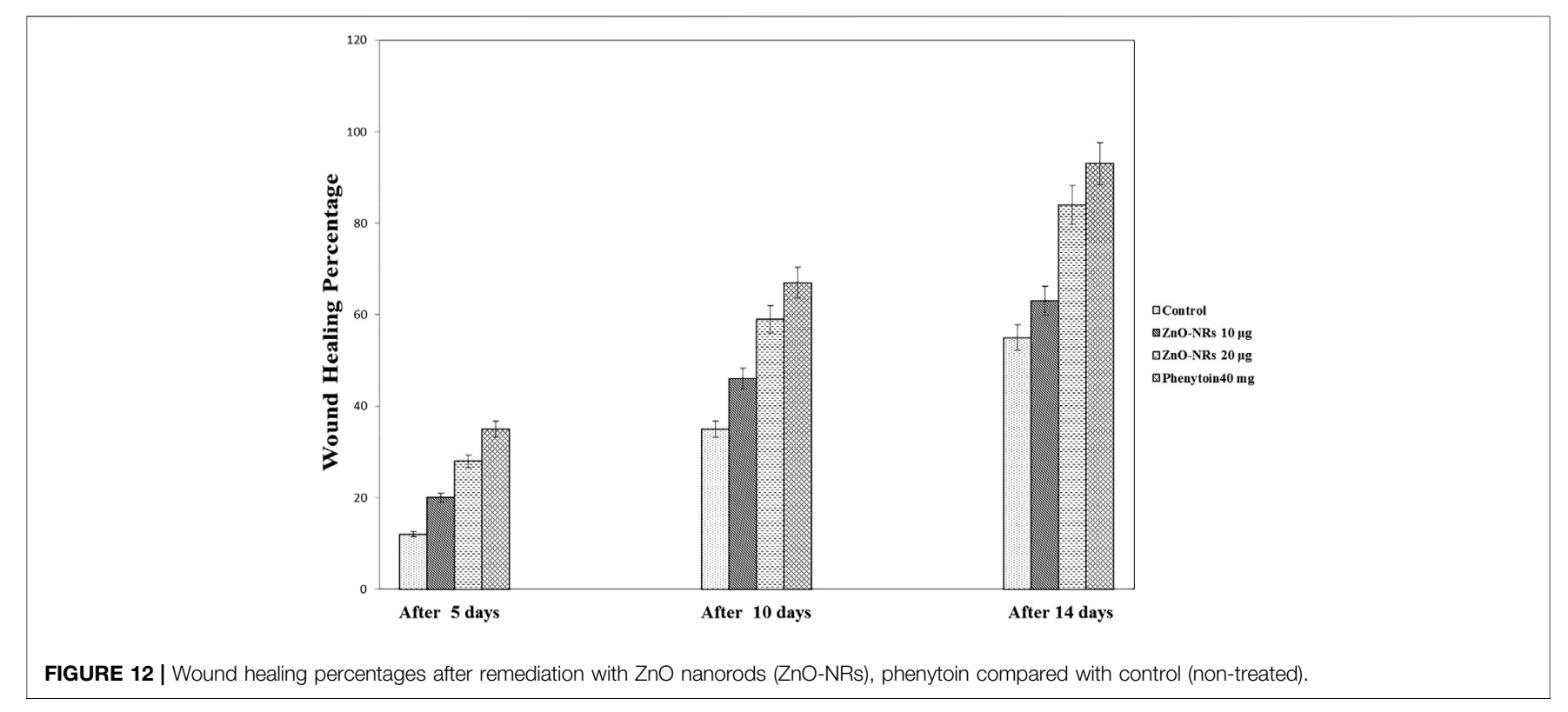




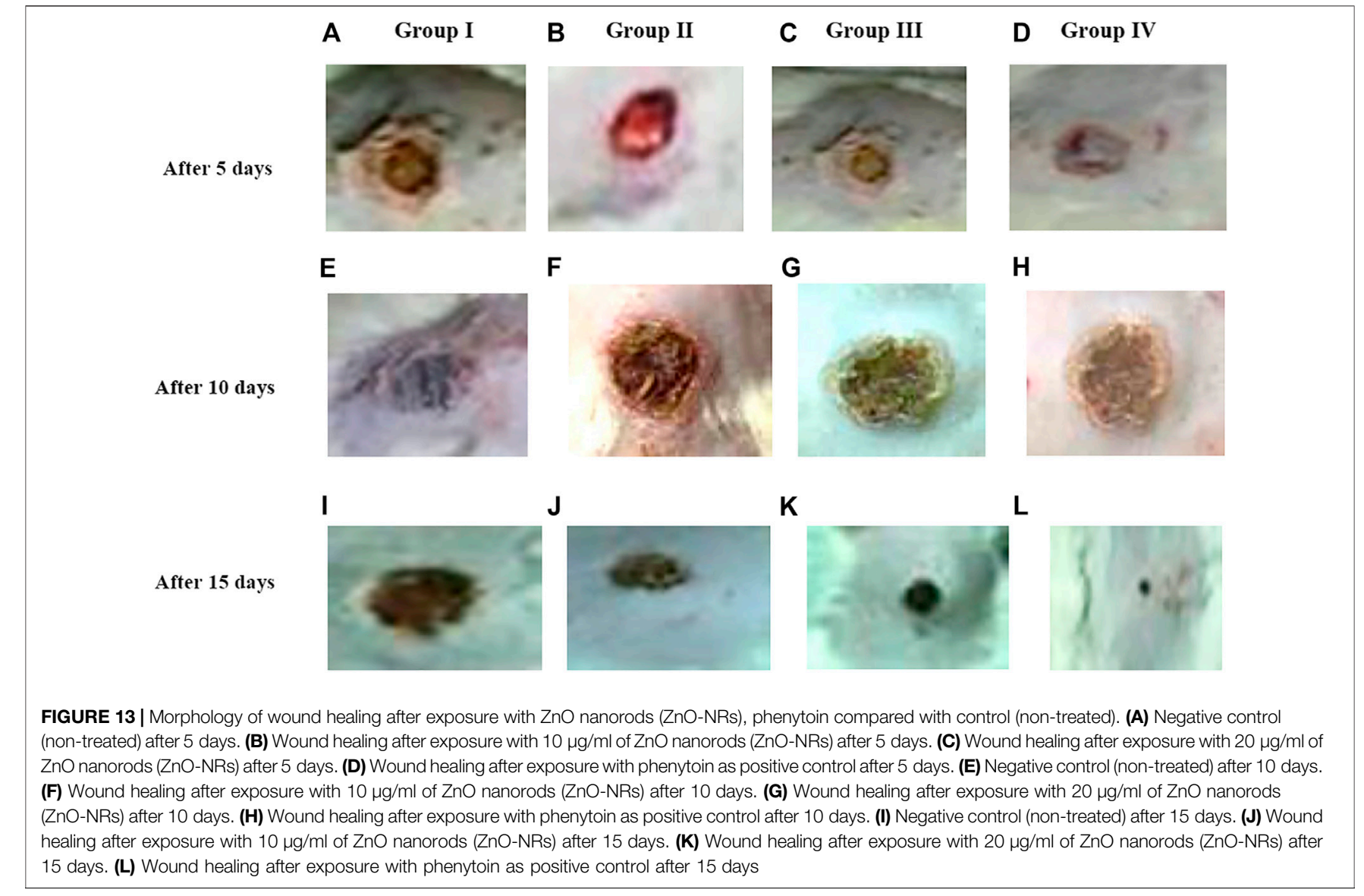

animal groups reveal cellular or rare endothelial cells with a score of zero, as shown in Figure 14E. However, in Figure 14 (F, G, and $\mathrm{H})$, a dermal layer indicated the beginning of neo-angiogenesis with a score of +2 for $\mathrm{ZnO}-\mathrm{NRs}$ with $20 \mu \mathrm{g} / \mathrm{ml}$ phenytoin, characterized by prominent linear arrangements and some tube formation. The animal group treated with $10 \mu \mathrm{g} / \mathrm{ml}$ of $\mathrm{ZnO}-\mathrm{NRs}$ revealed dispersed small aggregate endothelial cells without lumens with a score of +1 . Seven days after treatment, as Figures 14I-L (I, J, K, and L) revealed, wound tissues were filled with necrotic tissue and inflammatory neutrophils. The epidermis regeneration was significantly inhibited. Interestingly, new granulation tissues were created at the bottom of wounds in all animal groups, consisting of endothelial cells, fibroblast, and newly synthesized non-organized collagen. Figure 14I displayed that the control animal group has a score of +1 that revealed dispersed small aggregate endothelial cells without lumens. Figures 14J,K displayed the treated animal groups with $\mathrm{ZnO}$ NR concentrations of $10 \mu \mathrm{g} / \mathrm{ml}$ and $20 \mu \mathrm{g} \mu \mathrm{g} / \mathrm{ml}$, and phenytoin showed endothelial cells in all parts of the section with some tube formation with a score of +2 .

Interestingly, endothelial cell proliferation was accompanied by a new vessel number. It was assigned for readily identified capillary tube forming that included RBCs and small amounts of collagen, especially in animals treated at concentration of $20 \mu \mathrm{g} / \mathrm{ml}$ and had a score of +3 . Ten days after treatment, control prominent linear arrangements and some tube formation (score 1) were observed, as shown in Figure 14M. Otherwise, animal groups treated with phenytoin and $\mathrm{ZnO}-\mathrm{NR}$ concentration of $20 \mu \mathrm{g} / \mathrm{ml}$ showed capillary tube forming that includes RBCs and small amounts of collagen with a score of +3 , as shown in Figures 140,P, while $\mathrm{ZnO}-\mathrm{NR}$ concentration of $10 \mu \mathrm{g} / \mathrm{ml}$ had a score of +2 , as shown in Figure 14N. Fourteen days after treatment, fibroblasts and endothelial cells decreased in granulation with an excess of collagen fibers in the negative control (non-treated) with a score +2 , as shown in Figure 14Q. The negative control (untreated animals) and animal treated with $10 \mu \mathrm{g} / \mu \mathrm{l}$ of $\mathrm{ZnO}-\mathrm{NR}$ showed capillary tube formation which contained a red blood cell score of +3 as Figure 14R revealed. The animal group treated by $\mathrm{ZnO}-\mathrm{NR}$ concentration of $20 \mu \mathrm{g} / \mu \mathrm{l}$ and phenytoin showed vast vessels have more than four red cells containing layers of collagen in vessel walls with a score of four as Figures 14S,T showed. Finally, histological examination demonstrated that re-epithelization and new tissue formation in the treated groups' wound area.

\section{DISCUSSION}

Zinc oxide nanoparticles and their application in tissue engineering, as well as angiogenesis, were studied. Here in this study, we successfully fabricated green zinc oxide nanorods without complicated procedure or toxic chemicals to obtain a rod shape as other methods (Nouroozi and Farzaneh, 2011). 


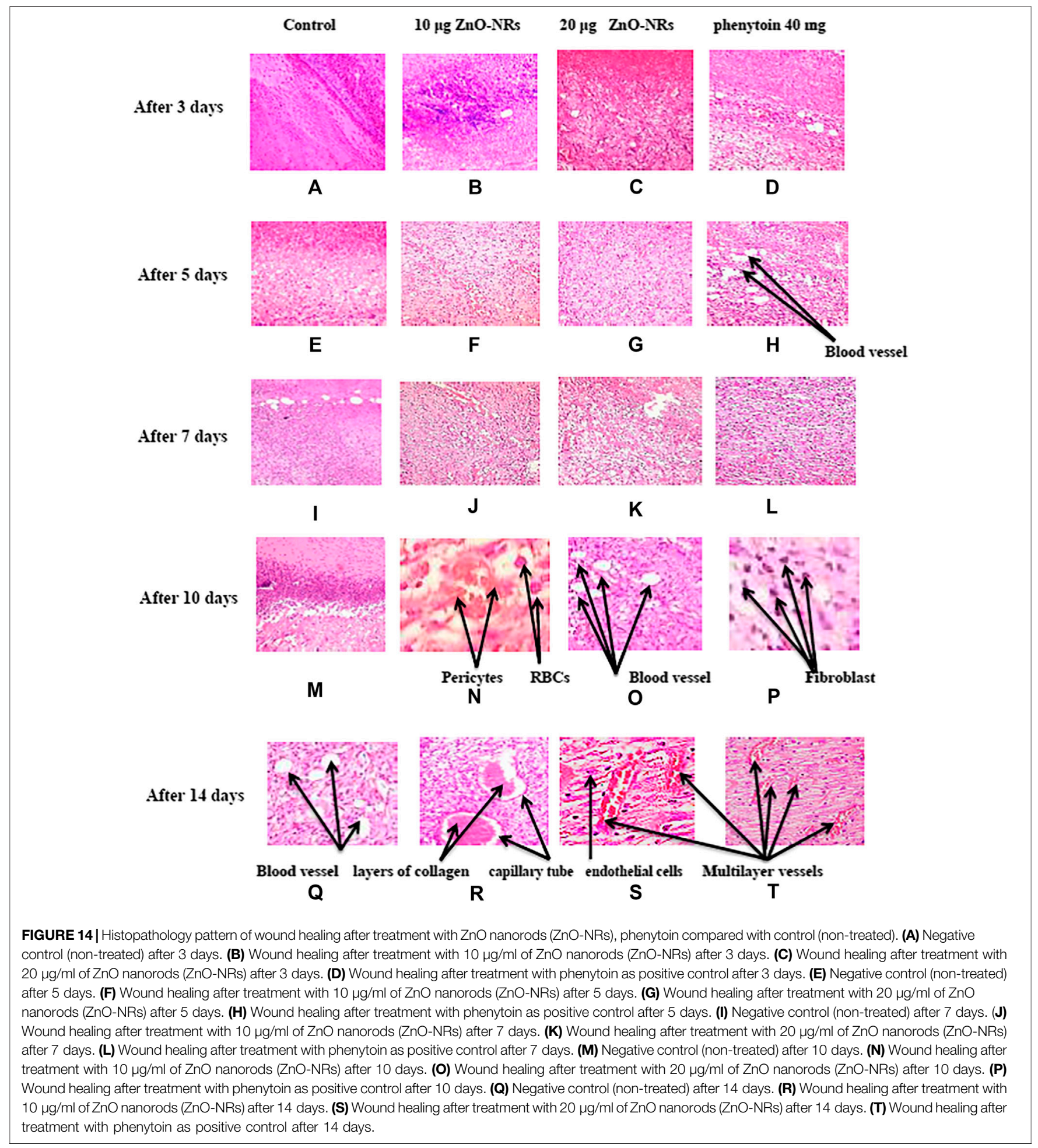

FTIR, XRD, and HR-TEM results confirmed the fabrication of $\mathrm{ZnO}$ nanorods. The plausible mechanism of synthesis of zinc oxide nanorods (ZnO-NRs) was carried out according to Bao et al. (2012). They mentioned that $\mathrm{ZnCl}_{2}$ dissolution to $\mathrm{Zn}^{2+}$ accumulated and oriented on the surface of the albumin template. The ions covered the albumin molecule, followed by thermal treatment for calcination at $300^{\circ} \mathrm{C}$ for $5 \mathrm{~h}$ so that $\mathrm{Zn}$ ion after thermal treatment will reshape $\mathrm{ZnO}$ into a rod shape (Bao et al., 2012). Our ICP results reveal quantitative zinc ions released from zinc oxide nanorods after time intervals. According to Oikawa et al., the $\mathrm{Zn}$ released from zinc oxide nanorods is time dependent (Tada-Oikawa et al., 2015). This report successfully investigated 
the effect of zinc oxide nanorods and $\mathrm{Zn}$ (II) ion released on angiogenesis markers using RT-PCR. The results of RT-PCR confirmed that $\mathrm{Zn}$ (II) ion released decreased VEGF gene expression. Hence, it suppresses the angiogenesis process. As Oikawa et al. mentioned, VEGF and its receptors can develop vascularization (Tada-Oikawa et al., 2015). On the other hand, upregulation of $\mathrm{ZnO}-\mathrm{NR}$ expression is concentration dependent. Previous studies reported that zinc ions released from suspended zinc oxide nanoparticles and zinc chloride restricted the expression of receptors related to vascularization (TadaOikawa et al., 2015). Interestingly, many preclinical models of micro-blood vessels grown on VEGF-A were capable of inducing cells to invade the underlying matrix to form capillary-like tubules (Pepper et al., 1992). VEGF is considered as the most important angiogenic mediator characterized to date (Cisowski et al., 2005). Previous studies suggest that hydrogen peroxide can induce VEGF in many cells and organs such as human keratinocytes (Sen et al., 2002), retinal pigment epithelial cells (Cisowski et al., 2005), endothelial cells (Sanchez et al., 2013), murine fibroblasts (Pepper et al., 1992), and macrophages (Cho et al., 2001). Also, $\mathrm{H}_{2} \mathrm{O}_{2}$ enhanced the skin wound healing in mice by the expression of VEGF (Sen et al., 2002). Interestingly, ZnONRs contribute to making new blood vessels (neovascularization). As previously reported, reactive oxygen species (ROS) have a great role in the microvascular process due to stimulating all angiogenic stages such as migration, cell proliferation, tube formation, and redox signaling. Our results confirmed that ROS generation by $\mathrm{ZnO}-\mathrm{NRs}$ is related to concentration. In contrast, $\mathrm{Zn}$ ions released showed no effect. Also, GSH is reduced with $\mathrm{ZnO}$-NRs concentration increased relatively due to the presence of ROS and $\mathrm{H}_{2} \mathrm{O}_{2}$. Also, the previous issue established that zinc oxide nanoparticles generate ROS components like $\mathrm{H}_{2} \mathrm{O}_{2}$ throughout photocatalysis (Hoffman et al., 1994). Both egg yolk and wound healing assay studies had displayed that $\mathrm{ZnO}$ nanorods were pro-angiogenic and mentioned that zinc oxide nanoflowers could make a new blood vessel. Patra et al. (2011) suggested that ROS activated angiogenesis by [EuIII $(\mathrm{OH})_{3}$ ] nanorods (Patra et al., 2011; Makhluf et al., 2008; Makhluf et al., 2008; Bhattacharya et al., 2007). In CAM assay, the decreased angiogenic property of $\mathrm{ZnO}-\mathrm{NRs}$ at higher concentration $(50 \mu \mathrm{g})$ due to the higher level ROS induced cell damage. Also, the released $\mathrm{Zn}$ (II) ions decreased the angiogenic property due to a negative effect on the angiogenic factors. The wound healing assay had shown the presence of a broad blood vessel network throughout. Endothelial cells contributed to reform and reshape the inner wall of blood vessels surrounding basal lamina and pericytes. It extends to a large cytoplasmic process over the surface of the vessel tube. The presence of pericytes around the blood vessels indicated mature vessels. Wound healing is considered as a complicated process following harm to the skin of the whole body. It included coordinated interactions between diverse immunological and biological systems for restoring the damaged cellular structure to its original state (Clark, 1985). Wound healing mechanisms including the processes above involve (1) growth factors; (2) cell proliferation, migration, and differentiation; (3) epithelialization, fibroplasia, and

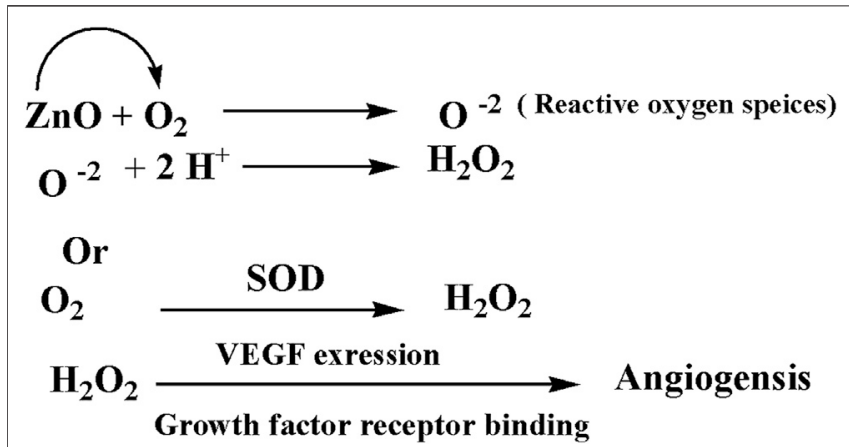

FIGURE 15 | A plausible mechanism of angiogenesis

angiogenesis; (4) wound contraction; and (5) remodeling (Velnar et al., 2009). Many mechanisms were accelerating injury healing, such as wound diminishing, epithelialization, and prevention of wound infection by bacteria that would delay and complicate the wound healing process (Lodhi and Singhai, 2013; Li et al., 2011). Zinc oxide nanomaterial has been known as an antibacterial agent (Jin et al., 2009). Collagen has a main role in extracellular protein in the granulation tissue of the wound healing process. Interestingly, it is a vital component that has a main role in incision solidity and impartiality of tissue matrix (Hassan et al., 2011). The wound healing process depends upon the controlled formation and deposition of novel collagens and their consequent maturation (Puratchikody et al., 2006). In our study, ZnO-NRs succeed in synthesizing a multilayer of collagen layers in vessel walls with red blood cells with a score of +4 , which means large vascular contains more than four red cells and multilayered blood vessels, including layers of collagen in vessel walls. There was a plausible mechanism about zinc oxide nanorod methodology, as Figure 15 displayed. We assumed that the $\mathrm{ZnO}$ nanorods could play an important role in ROS generation, especially $\mathrm{H}_{2} \mathrm{O}_{2}$. There are enormous mechanisms able to generate hydrogen peroxide in the cells. One of these mechanisms is the direct production of $\mathrm{O}_{2}$ and its interaction with water (Fridovich, 1975). Another one is converting superoxide to $\mathrm{H}_{2} \mathrm{O}_{2}$ through superoxide dismutase enzyme inside the cell generating $\mathrm{H}_{2} \mathrm{O}_{2}$ (Velnar et al., 2009; Bancroft et al., 2013). Hydrogen peroxide induces cells to express VEGF.

Interestingly, zinc oxide nanoparticles' exposure at a low dose $(10 \mathrm{mg} / \mathrm{l}$ and $20 \mathrm{mg} / \mathrm{l})$ does not have significant root growth inhibition for hormetic dose response for radish and ryegrass, respectively. Also, the hermetic phenomenon is evaluated by ATP measurement. The application of $\mathrm{Zn}$ NPs on seed germination and root growth of radish and ryegrass showed a hermetic dose response. In contrast, the plant species' root growth was restricted at a high concentration up to $200 \mathrm{mg} / \mathrm{l}$ (Iavicoli et al., 2018). Furthermore, Calabrese et al. (2010) managed the hormetic responses of cells to a range of metabolic and oxidative stressors (Calabrese et al., 2010). The presence of high concentration of zinc oxide nanoparticle generated oxidative stress. However, hydrogen peroxide can generate 
hydroxyl radical, a potent inducer of membrane lipid peroxidation (Calabrese et al., 2010).

Furthermore, endothelial cell proliferation, migration, and tube formation occurred due to due to the exiting of $\mathrm{ZnO}$ NRs. Finally, the fabrication of $\mathrm{ZnO}-\mathrm{NRs}$ could be applied in many tissue engineering applications such as skin tissue engineering, bone regeneration, and wound healing.

\section{CONCLUSION}

In this study, zinc oxide nanorods were fabricated and characterized. It has been synthesized via the green method using albumin eggshell. FTIR, XRD, and HR-TEM confirmed $\mathrm{ZnO}$ in a rod shape with a diameter of $84 \mathrm{~mm}$ and length of $281 \mathrm{~nm}$. Also, ICP evidence the presence of $\mathrm{Zn}$ ions released from $\mathrm{ZnO}$ nanorods, and quantitative release of $\mathrm{Zn}$ ions is time dependent. Egg yolk assay investigates the performance of zinc oxide nanorods to induce angiogenesis. In the case of $20 \mu \mathrm{g} / \mathrm{ml}$ of $\mathrm{ZnO}$ nanorods, there is an increase in the length of the blood vessel and size and junction. However, excess of $\mathrm{ZnO}$ nanorods and released $\mathrm{Zn}$ ions had reverse results. In the in vivo wound study, the data emphasized $\mathrm{ZnO}$ nanorods' ability for vascularization and rapid rate to remodeling the skin to its original shape due to epithelialization. Gene expression study demonstrated that enhancement of $\mathrm{ZnO}$ nanorods is a key of the angiogenic factors such as VEGF. Therefore, this report confirmed the importance of $\mathrm{ZnO}$ nanorods in tissue engineering material due to their ability to induce angiogenesis.

\section{DATA AVAILABILITY STATEMENT}

The original contributions presented in the study are included in the article/Supplementary Material; further inquiries can be directed to the corresponding author.

\section{REFERENCES}

Augustine, R., Dominic, E. A., Reju, I., Kaimal, B., Kalarikkal, N., and Thomas, S. (2014). Investigation of Angiogenesis and its Mechanism Using Zinc Oxide Nanoparticle-Loaded Electrospun Tissue Engineering Scaffolds. RSC Advances 93, 51528-51536. doi:10.1039/C4RA07361D

Ausprunk, D. H., Knighton, D. R., and Folkman, J. (1975). Vascularization of Normal and Neoplastic Tissues Grafted to the Chick Chorioallantois. Role of Host and Preexisting Graft Blood Vessels. Am. J. Pathol., 79 (3), $597,618$.

Bancroft, J. D., Stevans, A., and Turner, D. R. (2013). Theory and Practice of Histological Techniques. 4th Ed. Edinburgh, London, Melbourne, New York: Churchill Livingstone.

Bao, S.-J., Lei, C., Xu, M.-W., Cai, C.-J., and Jia, D.-Z. (2012). Environmentfriendly Biomimetic Synthesis of TiO2nanomaterials for Photocatalytic Application. Nanotechnology, 23 (20), 205601. doi:10.1088/0957-4484/23/ 20/205601

Barui, A. K., Veeriah, V., Mukherjee, S., Manna, J., Patel, A. K., Patra, S., et al. (2012). Zinc Oxide Nanoflowers Make New Blood Vessels. Nanoscale 4 (24), 7861-7869. doi:10.1039/c2nr32369a

\section{ETHICS STATEMENT}

The experimental procedure was approved by the Institutional Animal Care and Use Committee at Cairo University, Egypt (IACUC, CU-II-F-10-19) after the affirmative opinion of the Animal Protocols Evaluation Committee.

\section{AUTHOR CONTRIBUTIONS}

Conceptualization: $\mathrm{AH}, \mathrm{AM}, \mathrm{AE}$ and $\mathrm{EM}$; formal analysis: AM and $\mathrm{DE}$; funding acquisition: $\mathrm{AH}, \mathrm{AM}$ and $\mathrm{DE}$; investigation: $\mathrm{AH}, \mathrm{AM}$, $\mathrm{AE}$ and EM; methodology: $\mathrm{AH}, \mathrm{AM}, \mathrm{DE}, \mathrm{AE}$ and EM; project administration: $\mathrm{AH}, \mathrm{AM}, \mathrm{DE}$; Resource: $\mathrm{AM}$ and $\mathrm{DE}$; supervision: $\mathrm{AH}$; Validation: $\mathrm{AM}$ and $\mathrm{DE}$; visualization: $\mathrm{AM}$ and $\mathrm{DE}$; writing original draft: $\mathrm{AH}, \mathrm{AM}$; writing -review edition. $\mathrm{AH}, \mathrm{AM}$ and $\mathrm{AE}$. All author approved the final version of the manuscript.

\section{ACKNOWLEDGMENTS}

The authors thank Genetic Engineering and Biotechnology Research Institute (GBRI), University of Sadat City, Egypt. Also, the authors wish to thank Professor Aly Fahmy Mohamed for his support and equipping the laboratory to carry out this research work. Also, the authors thank Dr. Ahmed Ibrahim Abd El Maksoud for his support especially in the Biological experiments.

\section{SUPPLEMENTARY MATERIAL}

The Supplementary Material for this article can be found online at: https://www.frontiersin.org/articles/10.3389/fphar.2021.661217/ full\#supplementary-material

Supplementary Figure 1 | The image of preparation Zinc oxide nanorod.

Supplementary Figure 2 | Another image of TEM of Zinc oxide nanorod.

Bhattacharya, R., Patra, C. R., Verma, R., Kumar, S., Greipp, P. R., and Mukherjee, P. (2007). Gold Nanoparticles Inhibit the Proliferation of Multiple Myeloma Cells. Adv. Mater. 19 (5), 711-716. doi:10.1002/adma.200602098

Borah, D., Baruah, M. K., Saikia, P. P., Senapoty, K. K., Barua, M., and Singha, R. (2016). Structural Characterization and Surface Environment of ZnOnanoflowers. J. Mater. Environ. Sci. 7, 310-315.

Calabrese, V., Cornelius, C., Dinkova-Kostova, A. T., Calabrese, E. J., and Mattson, M. P. (2010). Cellular Stress Responses, the Hormesis Paradigm, and Vitagenes: Novel Targets for Therapeutic Intervention in Neurodegenerative Disorders. Antioxid. Redox Signaling 13 (11), 1763-1811. doi:10.1089/ars.2009.3074

Cho, M., Hunt, T. K., and Hussain, M. Z. (2001). Hydrogen Peroxide Stimulates Macrophage Vascular Endothelial Growth Factor Release. Am. J. physiologyheart circulatory Physiol. 280 (5), H2357-H2363. doi:10.1152/ajpheart.2001. 280.5.h2357

Cisowski, J., Łoboda, A., Józkowicz, A., Chen, S., Agarwal, A., and Dulak, J. (2005). Role of Heme Oxygenase-1 in Hydrogen Peroxide-Induced VEGF Synthesis: Effect of HO-1 Knockout. Biochem. biophysical Res. Commun. 326 (3), 670-676. doi:10.1016/j.bbrc.2004.11.083

Clark, R. A. F. (1985). Cutaneous Tissue Repair: Basic Biologic Considerations. I. J. Am. Acad. Dermatol. 13 (5), 701-725. doi:10.1016/s0190-9622(85)70213-7 
Clifford, D. H. (1984). "Preanesthesia, Anesthesia, Analgesia, and Euthanasia," in Laboratory Animal Medicine. Editors J. G. Fox, B. J. Cohen, and F. M. Loew (Orlando, Florida: Academic Press), 527-562. doi:10.1016/b978-0-12-2636202.50024-0

Cullity, B. D., and Stock, S. R. (2001). Elements of X-Ray Diffraction, Prentice-Hall. Upper Saddle River, NJ, 388.

Ejaz, S., Seok, K. B., and Woong Lim, C. (2006). A Novel Model of Image Acquisition and Processing for Holistic Quantification of Angiogenesis Disrupted by Application of Mainstream and Sidestream Cigarette Smoke Solutions. Environ. Toxicol. Pharmacol. 21 (1), 22-33. doi:10.1016/j.etap.2005. 05.011

Eliceiri, B. P., and Cheresh, D. A. (1999). The Role of av Integrins during Angiogenesis: Insights into Potential Mechanisms of Action and Clinical Development. J. Clin. Invest. 103 (9), 1227-1230. doi:10. $1172 /$ jci6869

Ellman, G. L. (1959). Tissue Sulfhydryl Groups. Arch. Biochem. Biophys. 82 (1), 70-77. doi:10.1016/0003-9861(59)90090-6

Ennett, A. B., and Mooney, D. J. (2002). Tissue Engineering Strategies for In Vivo Neovascularisation. Expert Opin. Biol. Ther. 2 (8), 805-818. doi:10.1517/ 14712598.2 .8 .805

Farmer, V. C. (1974). Infrared Spectra of Minerals. Mineralogical society. Vol. 4, 331-363.

Folkman, J. (1984). “Angiogenesis," in Biology of Endothelial Cells (Boston, MA: Springer), 412-428.

Fridovich, I. (1975). Superoxide Dismutases. Annu. Rev. Biochem. 44 (1), 147-159. doi:10.1146/annurev.bi.44.070175.001051

Hassan, S. W., Abubakar, M. G., Umar, R. A., Yakubu, A. S., Maishanu, H. M., and Ayeni, G. (2011). Pharmacological and Toxicological Properties of Leaf Extracts of Kingelia Africana (Bignoniaceae). J. Pharmacol. Toxicol. 6 (2), 124-132. doi:10.3923/jpt.2011.124.132

Hoffman, A. J., Carraway, E. R., and Hoffmann, M. R. (1994). Photocatalytic Production of $\mathrm{H} 2 \mathrm{O} 2$ and Organic Peroxides on Quantum-Sized Semiconductor Colloids. Environ. Sci. Technol. 28 (5), 776-785. doi:10. 1021/es00054a006

Huo, Y., Qiu, W.-Y., Pan, Q., Yao, Y.-F., Xing, K., and Lou, M. F. (2009). Reactive Oxygen Species (ROS) Are Essential Mediators in Epidermal Growth Factor (EGF)-stimulated Corneal Epithelial Cell Proliferation, Adhesion, Migration, and Wound Healing. Exp. Eye Res. 89 (6), 876-886. doi:10.1016/j.exer.2009. 07.012

Iavicoli, I., Leso, V., Fontana, L., and Calabrese, E. (2018). Nanoparticle Exposure and Hormetic Dose-Responses: An Update. Ijms 19 (3), 805. doi:10.3390/ ijms19030805

Jin, T., Sun, D., Su, J. Y., Zhang, H., and Sue, H.-J. (2009) Antimicrobial Efficacy of Zinc Oxide Quantum Dots againstListeria Monocytogenes, SalmonellaEnteritidis, andEscherichia coliO157:H7. J. Food Sci. 74, M46-M52. doi:10.1111/j.1750-3841.2008.01013.x

Lelkes, P. I., HahnK., L., Sukovich, D. A., Karmiol, S., and Schmidt, D. H. (1998). "On the Possible Role of Reactive Oxygen Species in Angiogenesis," in Oxygen Transport to Tissue XX (Boston, MA: Springer), 454, 295-310. doi:10.1007/9781-4615-4863-8_35

Li, K., Diao, Y., Zhang, H., Wang, S., Zhang, Z., Yu, B., and Yang, H. (2011). Tannin Extracts from Immature Fruits of TerminaliachebulaFructus Retz. Promote Cutaneous Wound Healing in Rats. BMC Complement. Altern. Med. 11 (1), 1-9. doi:10.1186/1472-6882-11-86

Lodhi, S., and Singhai, A. K. (2013). Wound Healing Effect of Flavonoid Rich Fraction and Luteolin Isolated from Martynia Annua Linn. On Streptozotocin Induced Diabetic Rats. Asian Pac. J. Trop. Med. 6 (4), 253-259. doi:10.1016/ s1995-7645(13)60053-x

Ma, N. (2000). Iozzo RV. Fibroblast Growth Factor-2. Int. J. Biochem. Cel Biol 32, $115-120$.

Makhluf, S. B.-D., Arnon, R., Patra, C. R., Mukhopadhyay, D., Gedanken, A., Mukherjee, P., et al. (2008). Labeling of Sperm Cells via the Spontaneous Penetration of Eu3+Ions as Nanoparticles Complexed with PVA or PVP. J. Phys. Chem. C 112 (33), 12801-12807. doi:10.1021/jp804012b

Marklund, S. L., Westman, N. G., Lundgren, E., and Roos, G. (1982). Copperand Zinc-Containing Superoxide Dismutase, Manganese-Containing Superoxide Dismutase, Catalase, and Glutathione Peroxidase in Normal and Neoplastic Human Cell Lines and Normal Human Tissues. Cancer Res. 42 (5), 1955-1961.

Norrby, K. (2006). In vivo models of Angiogenesis. J. Cell. Mol. Med. 10 (3), 588-612. doi:10.1111/j.1582-4934.2006.tb00423.x

Nouroozi, F., and Farzaneh, F. (2011). Synthesis and Characterization of Brush-like ZnO Nanorods Using Albumen as Biotemplate. J. Braz. Chem. Soc. 22 (3), 484-488. doi:10.1590/s0103-50532011000300011

Patra, C. R., Kim, J.-H., Pramanik, K., d'Uscio, L. V., Patra, S., Pal, K., et al. (2011). Reactive Oxygen Species Driven Angiogenesis by Inorganic Nanorods. Nano Lett. 11 (11), 4932-4938. doi:10.1021/nl2028766

Patterson, A. L. (1939). The Scherrer Formula for X-Ray Particle Size Determination. Phys. Rev., 56(10), 978, 982.pdoi:10.1103/physrev. 56.978

Pechan, P. A., Chowdhury, K., and Seifert, W. (1992). Free Radicals Induce Gene Expression of NGF and bFGF in Rat Astrocyte Culture. Neuroreport 3 (6), 469-472. doi:10.1097/00001756-199206000-00003

Pepper, M. S., Ferrara, N., Orci, L., and Montesano, R. (1992). Potent Synergism between Vascular Endothelial Growth Factor and Basic Fibroblast Growth Factor in the Induction of Angiogenesis In Vitro. Biochem. biophysical Res. Commun. 189 (2), 824-831. doi:10.1016/0006$291 \mathrm{x}(92) 92277-5$

Petrova, T. V., Makinen, T., and Alitalo, K. (1999). Signaling via Vascular Endothelial Growth Factor Receptors. Exp. Cel. Res. 253 (1), 117-130. doi:10.1006/excr.1999.4707

Pfaffl, M. W. (2001). A New Mathematical Model for Relative Quantification in Real-Time RT-PCR. Nucleic Acids Res. 29 (9), e45. doi:10.1093/nar/29. 9.e45

Pitiakoudis, M., Giatromanolaki, A., Iliopoulos, I., Tsaroucha, A., Simopoulos, C., and Piperidou, C. (2004). Phenytoin-induced Lymphocytic Chemotaxis, Angiogenesis and Accelerated Healing of Decubitus Ulcer in a Patient with Stroke. J. Int. Med. Res. 32 (2), 201-205. doi:10.1177/ 147323000403200213

Puratchikody, A., Devi, C., and Nagalakshmi, G. (2006). Wound Healing Activity of cyperus Rotundus Linn. Indian J. Pharm. Sci., 68(1), 97. doi:10.4103/0250474x.22976

Rasmussen, J. W., Martinez, E., Louka, P., and Wingett, D. G. (2010). Zinc Oxide Nanoparticles for Selective Destruction of Tumor Cells and Potential for Drug Delivery Applications. Expert Opin. Drug Deliv. 7 (9), 1063-1077. doi:10.1517/ 17425247.2010.502560

Rhee, S. G. (2006). CELL SIGNALING: H2O2, a Necessary Evil for Cell Signaling. Science 312 (5782), 1882-1883. doi:10.1126/science.1130481

Rouwkema, J., Rivron, N. C., and van Blitterswijk, C. A. (2008). Vascularization in Tissue Engineering. Trends Biotechnol. 26 (8), 434-441. doi:10.1016/j.tibtech. 2008.04.009

Roy, S., Khanna, S., Nallu, K., Hunt, T. K., and Sen, C. K. (2006). Dermal Wound Healing Is Subject to Redox Control. Mol. Ther. 13 (1), 211-220. doi:10.1016/j. ymthe.2005.07.684

Sanchez, A., Tripathy, D., Luo, J., Yin, X., Martinez, J., and Grammas, P. (2013). Neurovascular Unit and the Effects of Dosage in VEGF Toxicity: Role for Oxidative Stress and Thrombin. Jad 34 (1), 281-291. doi:10.3233/ jad- 121636

Sen, C. K., Khanna, S., Babior, B. M., Hunt, T. K., Ellison, E. C., and Roy, S. (2002). Oxidant-induced Vascular Endothelial Growth Factor Expression in Human Keratinocytes and Cutaneous Wound Healing. J. Biol. Chem. 277 (36), 33284-33290. doi:10.1074/jbc.m203391200

Silverstein, R. M., and Bassler, G. C. (1962). Spectrometric Identification of Organic Compounds. J. Chem. Educ., 39(11), 546. doi:10.1021/ed039p546

Suri, C., Jones, P. F., Patan, S., Bartunkova, S., Maisonpierre, P. C., Davis, S., et al. (1996). Requisite Role of Angiopoietin-1, a Ligand for the TIE2 Receptor, during Embryonic Angiogenesis. Cell 87 (7), 1171-1180. doi:10.1016/s00928674(00)81813-9

Tada-Oikawa, S., Ichihara, G., Suzuki, Y., Izuoka, K., Wu, W., Yamada, Y., et al. (2015). Zn(II) Released from Zinc Oxide Nano/micro Particles Suppresses Vasculogenesis in Human Endothelial Colony-Forming Cells. Toxicol. Rep. 2, 692-701. doi:10.1016/j.toxrep.2015.04.003

Thomas, C. E. (1990). Ethylamine. Wounds 3, 95-101. doi:10.1016/b978-0-44481316-9.50021-9 
Velnar, T., Bailey, T., and Smrkolj, V. (2009). The Wound Healing Process: an Overview of the Cellular and Molecular Mechanisms. J. Int. Med. Res. 37 (5), 1528-1542. doi:10.1177/147323000903700531

Xia, C., Meng, Q., Liu, L.-Z., Rojanasakul, Y., Wang, X.-R., and Jiang, B.-H. (2007). Reactive Oxygen Species Regulate Angiogenesis and Tumor Growth through Vascular Endothelial Growth Factor. Cancer Res. 67 (22), 10823-10830. doi:10. 1158/0008-5472.can-07-0783

Zhang, Y., Nayak, T., Hong, H., and Cai, W. (2013). Biomedical Applications of Zinc Oxide Nanomaterials. Cmm 13 (10), 1633-1645. doi:10.2174/ 1566524013666131111130058

Conflict of Interest: The authors declare that the research was conducted in the absence of any commercial or financial relationships that could be construed as a potential conflict of interest.
Publisher's Note: All claims expressed in this article are solely those of the authors and do not necessarily represent those of their affiliated organizations, or those of the publisher, the editors and the reviewers. Any product that may be evaluated in this article, or claim that may be made by its manufacturer, is not guaranteed or endorsed by the publisher.

Copyright (C) 2021 Hassan, Elebeedy, Matar, Fahmy Mohamed Elsayed and Abd El Maksoud. This is an open-access article distributed under the terms of the Creative Commons Attribution License (CC BY). The use, distribution or reproduction in other forums is permitted, provided the original author(s) and the copyright owner(s) are credited and that the original publication in this journal is cited, in accordance with accepted academic practice. No use, distribution or reproduction is permitted which does not comply with these terms. 